\title{
Evaluation of Groundwater Quality for Drinking and Irrigation in Central Tongu District of the Volta Region of Ghana
}

\author{
*Christian Avi ${ }^{1}$, Millicent Tettey ${ }^{1}$ and Kojo Ayitey ${ }^{1}$ \\ 1. Science Laboratory Technology Department Accra Technical University, Accra, Gha \\ *e-mail: christianavi@yahoo.com
}

\begin{abstract}
This work was done to assess the physical and chemical qualities of groundwater in some predominantly farming communities in the Central Tongu District of the Volta Region of Ghana. Water samples from 8 boreholes and one hand dug well were assessed for the water quality parameters. The $\mathrm{pH}$ of the groundwater samples range between 6.42 to 7.40 with a mean value of $7.07( \pm 0.33)$. The $\mathrm{pH}$ range fall within the WHO standards for drinking water and within the permissible limit for irrigated agriculture water $\mathrm{pH}$ of $6.5-9.2$. The main hydrochemical facies that has been identified in the study area is the $\mathrm{Na}-\mathrm{K}-\mathrm{HCO}_{3}$ water type. Major irrigation water quality parameters assessed included sodium adsorption ratio, residual sodium carbonate, sodium percent and salinity hazard. Results of the irrigation water quality parameters studied showed that water from majority of the boreholes are unsuitable for irrigation. The water samples are salty and hard and only two (2) out of the nine sampling sites representing $22.22 \%$ of the samples analyzed met the WHO standard of $500 \mathrm{mg} / 1 \mathrm{CaCO}_{3}$ for drinking water and will be safe for drinking.
\end{abstract}

Key words: Groundwater, Chemical classification, Salinity hazard, SAR, Drinking water.

DOI: $10.7176 / \mathrm{JEES} / 9-10-16$

Publication date:October $31^{\text {st }} 2019$

\section{Introduction}

Groundwater supports drinking water supply, livestock needs, irrigation, industrial and many other commercial activities. The quality of ground water depends on various chemical constituents and their concentration, which are mostly derived from the geological data of the particular region. Groundwater is generally less susceptible to contamination and pollution when compared to surface water bodies (Oteze 1991; Jalali 2005). The quality of groundwater is constantly changing in response to daily, seasonal and climatic factors. Continuous monitoring of water quality parameters is highly crucial because changes in the quality of water has far reaching consequences in terms of its effects on man and biota (Ackah et al, 2011). Availability of water by itself is not a guaranty for sustainable development, but its fitness for specific purposes like irrigation, industrial and domestic uses (Muhammad et al. 2002).

In most of the communities groundwater is the main source of water and most of the inhabitants are engaged in farming and some are into cattle rearing. A number of chemical contaminants have been shown to cause adverse health effects in humans as a consequence of prolonged exposure through drinking water from various sources. Much of ill health which affects humanity, especially in the developing countries can be traced to lack of safe and wholesome water supply (Kumar 2004; Mahananda et al 2005). Suitability of water for various uses depends on type and concentration of dissolved minerals and groundwater has more mineral composition than surface water (Mirribasi et al., 2008).

The chemical parameters of groundwater play a significant role in classifying and assessing water quality. Thus, there is a need to evaluate irrigation water quality and this is hinged majorly on alkalinity (sodium hazard) and salinity hazard (total soluble salt content) of such waters (Silva 2004). The criteria used in the classification of waters for a particular purpose considering the individual concentration may not find its suitability for other purposes and better results can be obtained only by considering the combined chemistry of all the ions rather than individual or paired ionic characters (Hem, 1985). Chemical classification also throws light on the concentration of various predominant cations, anions and their interrelationships (Sadashivaiah et al, 2008).

\section{The Study area}

The Central Tongu District lies within latitudes $5047^{\circ} \mathrm{N}$ to $60^{\circ} \mathrm{N}$ and longitude $005^{\circ} \mathrm{E}$ to 0045 , the size is 1,460 square kilometres. The District shares boundaries with Akatsi East and Akatsi West to the east, to the south with South Tongu District and Ada East Districts respectively, to the west with Dangme West District and to the north with North Tongu Districts. Households in the district derive their drinking water from diverse sources but the five main sources are river/stream, dugout wells, standpipes, and boreholes, which together constitute the main sources for 91.2 percent of households. The District lies within the tropical savannah grassland zone. The district is predominantly covered with medium to moderately coarse alluvial soils particularly in areas adjoining the Volta 
River. Below these categories of soils are the heavier clayey soils which are very common in most parts of the District. Areas between Adidome, Anfoe, Kpedzeglo, Mafi-Kumase, Sasekpe and Bakpa-Avedo consist of moderately coarse or sandy loams which drain easily and are suitable for agricultural purposes. The main mineral deposits in the district are: - Clay, Oyster Shells, Nepheline, Gneiss, Sand and Granite. Many of these have not been exploited economically (GSS, 2014).

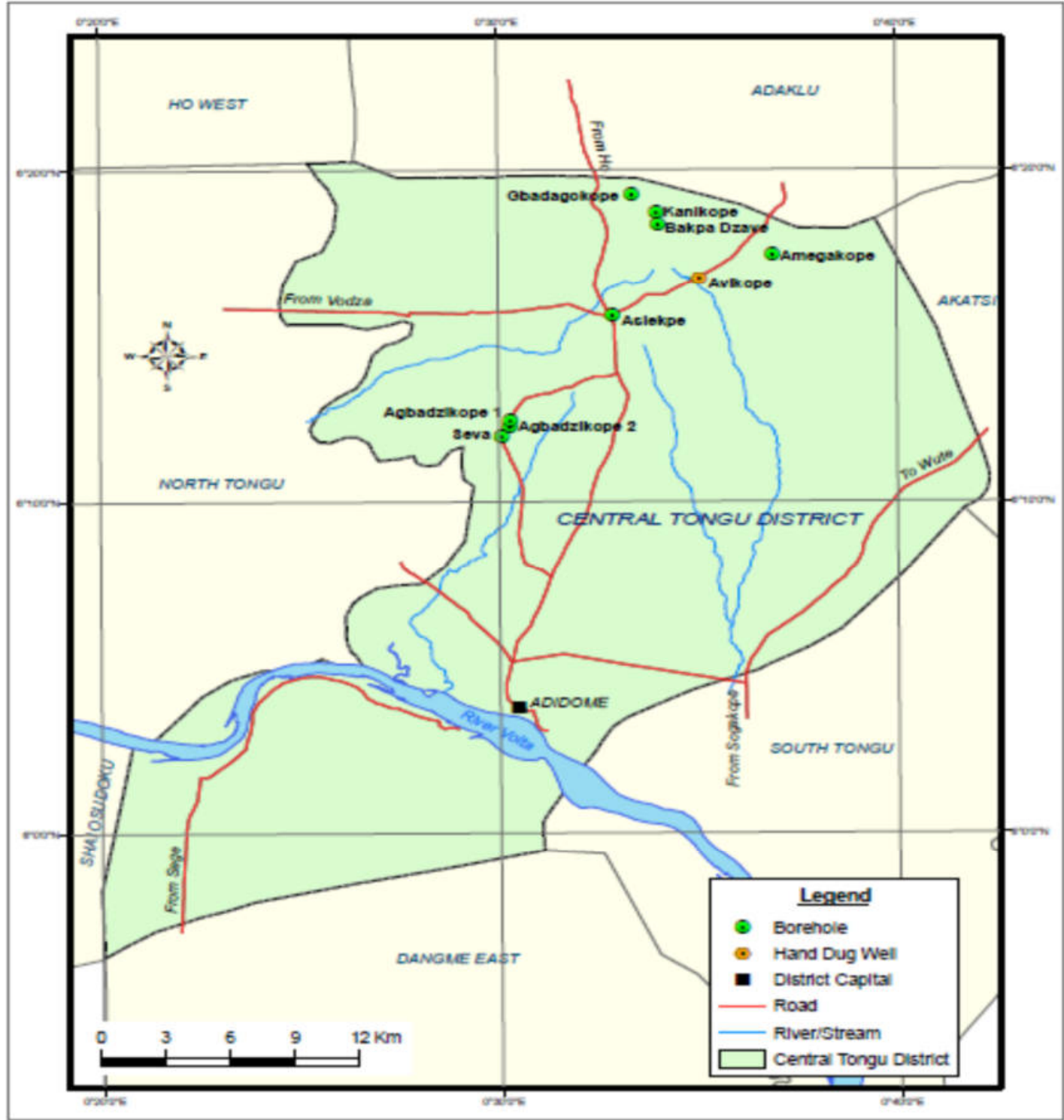

Figure 1: Sampling Locations in Central Tongu

\section{Methodology}

Nine (9) sampling sites were identified and selected for the investigation comprising eight (8) boreholes and a hand-dug well. The water samples were collected in $500 \mathrm{~cm}^{3}$ acid-washed high density polyethylene sampling bottles after filtering through $0.45-\mu \mathrm{m}$ filters on acetate cellulose with a hand operated vacuum pump. The filtered water samples for metal analysis were acidified with $1 \% \mathrm{HNO}_{3}$ to keep metals in solution. The temperature, $\mathrm{pH}$, electrical conductivity and total dissolved solids values were determined on site using the calibrated HACH sensION MM 150 Potable Multi Meter. Alkalinity titrations were also carried out at the sampling sites with 0.16 $\mathrm{N} \mathrm{H}_{2} \mathrm{SO}_{4}$ using HACH Digital Titrator Model 16900. The samples collected were stored in an ice chest containing ice cubes and transported to the laboratory for analysis. 
Total hardness, calcium and magnesium were determined using EDTA Titrimetric method (APHA, 1998). The HACH DR6000 Spectrophotometer and SulfaVer 4 (Turbidimetry) and the Spand 2 methods were used for the determination of sulphate and fluoride respectively (USEPA, 2014). Concentrations of $\mathrm{Na}^{+}$and $\mathrm{K}^{+}$were determined using flame photometer, chloride was determined by titration (Argentometric Method) with standard silver nitrate.

\section{Results and Discussion}

A statistical summary of the hydrochemical parameters determined in the groundwater samples is presented in Table 1 and the groundwater quality classification for the various parameters are presented in Tables 2 and 3.

Table: 1.0 Statistical summary of parameters determined at the various sites in the Central Tongu District

\begin{tabular}{|c|c|c|c|c|c|c|}
\hline & Min & Max & Median & Mean & SD & WHO Standard \\
\hline $\mathrm{pH}$ & 6.42 & 7.40 & 7.09 & 7.07 & 0.33 & $6.5-8.5$ \\
\hline Temperature & 28.9 & 31.67 & 30.2 & 29.94 & 0.91 & \\
\hline $\mathrm{EC}$ & 720 & 4453.3 & 2217.5 & 2332.0 & 1418.26 & 1500 \\
\hline TDS & 172.45 & 1061.67 & 467.67 & 487.02 & 311.12 & 1000 \\
\hline Alkalinity & 271.33 & 952.22 & 432.0 & 574.75 & 280.16 & 200.0 \\
\hline Sodium & 134.64 & 856.40 & 444.92 & 450.13 & 267.90 & 200.0 \\
\hline Potassium & 17.34 & 64.69 & 48.84 & 45.02 & 17.05 & \\
\hline Nitrate & 24.11 & 52.77 & 26.33 & 29.00 & 9.04 & 50.0 \\
\hline Calcium & 36.79 & 191.6 & 99.87 & 99.17 & 52.71 & 200.0 \\
\hline Magnesium & 25.8 & 150.67 & 69.72 & 72.22 & 37.9 & 150.0 \\
\hline Bicarbonate & 331.03 & 1372.6 & 815.77 & 822.19 & 415.57 & \\
\hline Chloride & 85.06 & 610.14 & 305.48 & 298.79 & 180.53 & 250.0 \\
\hline Sulphate & 7.00 & 120.00 & 92.00 & 73.52 & 40.87 & 250.0 \\
\hline Total Hardness & 220.00 & 1513.33 & 846.00 & 782.96 & 435.18 & 500.00 \\
\hline
\end{tabular}

\section{$3.1 \mathrm{pH}$}

The $\mathrm{pH}$ of the groundwater samples is generally slightly acidic to alkaline in the range of 6.42 to 7.40 with mean and median values of 7.07 and 7.09 respectively (Table 1). These values fall within the WHO (2004), standards for drinking water of 6.5- 8.5, however one borehole at Asiekpe had a $\mathrm{pH}$ of 4.2 which is below the WHO recommended limit. The $\mathrm{pH}$ vales are also within the range 4.5- 9.0 for natural water (Langmuir, 1997; Kortatsi, 2007) and were within the permissible limit for irrigated agriculture water $\mathrm{pH}$ of 6.5-9.2 (DOE 1997). This shows that the borehole water in the area is safe for agricultural, recreational and domestic uses based on the $\mathrm{pH}$ values.

\subsection{Total Hardness}

Total hardness of the water samples under study showed high values and ranged from 220.00 to $1513.33 \mathrm{mg} / \mathrm{L}$ $\mathrm{CaCO}_{3}$ with a mean value of $782.96 \mathrm{mg} / 1 \mathrm{CaCO}_{3}$ and standard deviation of 435.18 (Table 1). By the classification of Durfor and Becker (1964), all sampling sites representing 100\% of the samples analyzed were very hard since 
they were all above $180 \mathrm{mg} / \mathrm{L} \mathrm{CaCO}_{3}$ (Table 2). From the results four (4) out of the nine groundwaters, representing $44.44 \%$ of the samples analyzed met the WHO standard of $500 \mathrm{mg} / 1 \mathrm{CaCO}_{3}$ for drinking water and will be safe for drinking (WHO, 2004). The remaining $55.56 \%$ of the samples were however, above the WHO standard for drinking water. Water hardness has no known adverse effects; however, some evidence indicates its role in heart disease (Schroeder, 1960). Hard water is unsuitable for domestic use. Total alkalinity values were in the range of $271.33-952.33 \mathrm{mg} / \mathrm{l}$ with a mean value of $574.75 \mathrm{mg} / \mathrm{l}$. All the water samples in the study area have alkalinity values well above the WHO limit of $200.0 \mathrm{mg} / \mathrm{L}$ (WHO, 2004).

Table 2: Classification of water from Central Tongu based on hardness

\begin{tabular}{ccc}
\hline $\begin{array}{c}\text { Hardness mg/L } \\
\left(\mathrm{CaCO}_{3}\right)\end{array}$ & Classification & Samples \\
\hline $0-60$ & Soft & - \\
$61-120$ & Moderately Hard & - \\
$121-180$ & Hard & - \\
$>180$ & Very Hard & 9 \\
\hline
\end{tabular}

(After Durfor and Becker, 1964)

\subsection{Hydrochemical Facies}

The chemical composition of the water samples from the study area is shown on the Piper diagram in Fig. 2.0. This plot includes two triangles, one for plotting cations and the other for plotting anions. The cations and anion fields are combined to show a single point in a diamond-shaped field, from which inference is drawn on the basis of hydro-geochemical facies concept. (Sadashivaiah, et al, 2008). .

The results reveal that majority of the boreholes and hand dug well plot in the alkalis $(\mathrm{Na}+\mathrm{K})$ sub-division and exceed the alkaline earth $(\mathrm{Ca}+\mathrm{Mg})$ and the samples also plot in the sub-division of the weak acids $\left(\mathrm{CO}_{3}{ }^{2-}+\mathrm{HCO}_{3}^{-}\right)$ and exceed the strong acid $\left(\mathrm{SO}_{4}{ }^{2-}+\mathrm{Cl}^{-}\right)$type. The major hydrochemical facies in the study area belong to $\mathrm{Na}^{+}-$ $\mathrm{K}^{+}-\mathrm{HCO}_{3}^{-}$water type (Fig. 2.0).

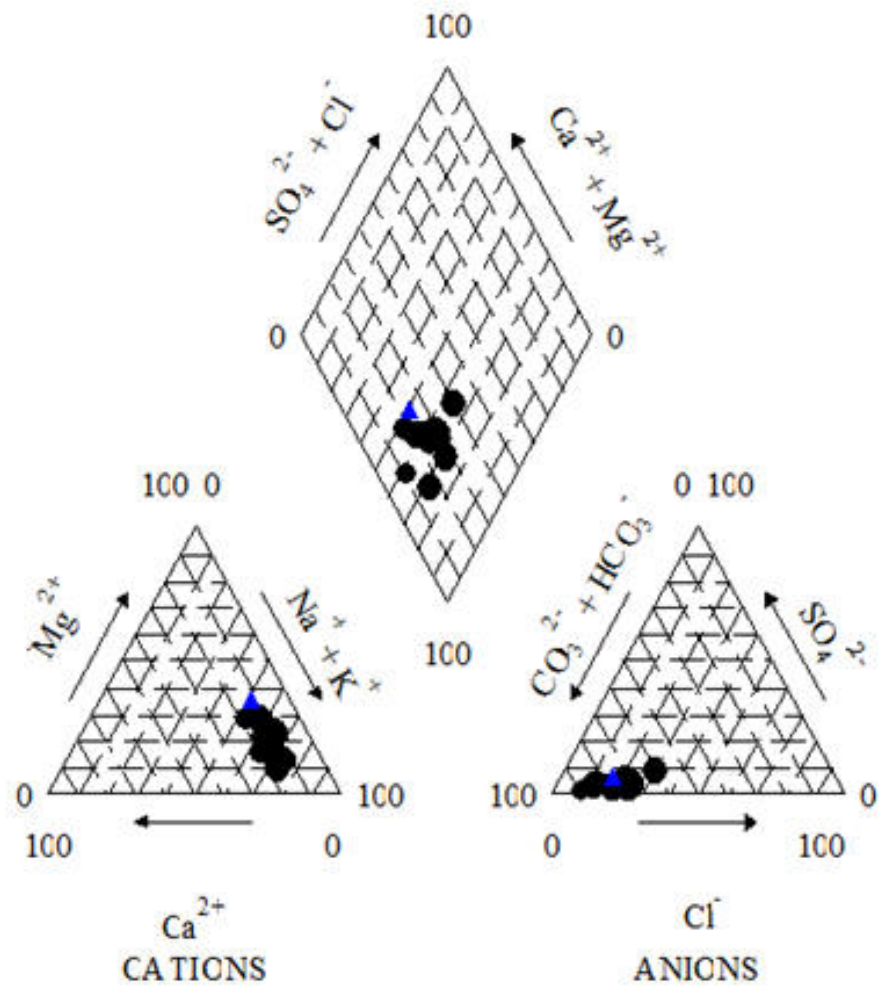

Figure 2: Phase diagram for water samples from Central Tongu. 
3.4 Classification of Groundwater

Electrical Conductivity (EC) and $\mathrm{Na}+$ play a vital role in suitability of water for irrigation. Sodium adsorption ratio (SAR), ratio of dissolved sodium as $\% \mathrm{Na}$, or residual sodium carbonate (RSC) might equally be used for calculating a value which can be utilized as an index of ground water suitability for irrigation purposes (Shaki and Adeloye, 2006).

The sodium in irrigation waters is usually denoted as per cent sodium and can be determined using the following formula (Al-Salim 2009; Siamak and Srikantaswamy 2009).

$$
\% \mathrm{Na}=(\mathrm{Na}) \times 100 /\left(\mathrm{Ca}^{2+}+\mathrm{Mg}^{2+}+\mathrm{Na}^{+}+\mathrm{K}^{+1}\right)
$$

where the quantities of $\mathrm{Ca}^{2+}, \mathrm{Mg}^{2+}, \mathrm{Na}^{+}$and $\mathrm{K}^{+}$are expressed in milliequivalents per litre (meq/L).

In waters having high concentration of bicarbonate, there is tendency for calcium and magnesium to precipitate as the water in the soil becomes more concentrated. As a result, the relative proportion of sodium in the water is increased in the form of sodium carbonate.

Residual Sodium Carbonate (RSC) is calculated using the following equation:

$$
\mathrm{RSC}=\left(\mathrm{HCO}_{3}{ }^{-}+\mathrm{CO}_{3}{ }^{2-}\right)-\left(\mathrm{Ca}^{2+}+\mathrm{Mg}^{2+}\right)
$$

where all ionic concentrations are expressed in $\mathrm{meq} / \mathrm{L}$.

The classification of groundwater samples from the study area with respect to Salinity Hazard (EC), TDS, \%Na, SAR and RSC is represented in Table 3.0

From the table all the RSC values are greater than 2.5 indicating that they are not safe for irrigation. According to the US Department of Agriculture, water having more than $2.5 \mathrm{meq} / \mathrm{L}$ of RSC is not suitable for irrigation purposes. Sodium adsorption ratio (SAR) is a measure of the amount of sodium $\left(\mathrm{Na}^{+}\right)$relative to calcium $\left(\mathrm{Ca}^{2+}\right)$ and magnesium $\left(\mathrm{Mg}^{2+}\right)$ in the water extract from saturated soil paste. SAR is an important parameter for the determination of suitability of water for irrigation purpose because it is responsible for the sodium hazard in irrigation water (Siamak and Srikantaswamy, 2009).

SAR is computed as

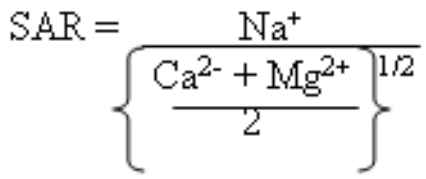

where all ionic concentrations are expressed in meq/L

The total concentrations of soluble salts in irrigation water can be classified as low ( $\mathrm{S} 1:<10)$, medium(S2:10-18), high(S3:18-26) and very high( S4:>26) (Rao, 2006). The zones (S1-S4) have the value of EC less than $250 \mu \mathrm{S} / \mathrm{cm}$, $250-750 \mu \mathrm{S} / \mathrm{cm}, 750-2250 \mu \mathrm{S} / \mathrm{cm}$ and more than $2250 \mu \mathrm{S} / \mathrm{cm}$ respectively.

From Table 4, based on salinity hazard, only one (1) groundwater sample is found in the C2 water quality class, which means it is good for irrigation. The rest occur in the doubtful (C3) and Unsuitable (C4) water quality class, thus unsuitable for irrigation. With respect to $\% \mathrm{Na}$, it is observed that $4(44.44 \%)$ of the water samples fall within the permissible water class whilst $5(55.56 \%)$ of the water samples fall in the doubtful class (Table 4$)$.

Approximately $66.67 \%$ (i.e 6) of the 9 groundwater samples have SAR values less than 10 and are classified as excellent for irrigation. The remaining $3(33.3 \%)$ have values that ranged between 10 and 18 and as such are good for irrigation. The classification of water for irrigation can be determined by graphically plotting the SAR values against the EC values on the US salinity (USSL) diagram (Ravikumar et al, 2015) as shown in Figure 3. 
Table 3. Classification of water samples based on EC, \%Na and SAR.

\begin{tabular}{|c|c|c|c|c|c|}
\hline Parameter & Range & Water quality class & $\begin{array}{ll}\text { No. } & \text { of } \\
\text { Samples } & \\
\end{array}$ & Range & $\%$ \\
\hline $\mathrm{EC}$ or salinity $(\mu \mathrm{S} / \mathrm{cm})$ & $100-250$ & Excellent ( $\mathrm{C} 1)$ & - & - & - \\
\hline \multirow[t]{3}{*}{ Hazard classification } & $250-750$ & Good $\quad(\mathrm{C} 2)$ & 1 & 720 & 11.11 \\
\hline & $750-2,250$ & Doubtful （C3) & 4 & $758-2,217$ & 44.44 \\
\hline & $>2,250$ & Unsuitable ( $\mathrm{C} 4)$ & 4 & $2853-4453$ & 44.44 \\
\hline Total dissolved & $<500$ & Desirable for Drinking & 5 & $181.9-467.67$ & 55.56 \\
\hline \multirow[t]{3}{*}{ Solids(TDS) (ppm) } & $500-1,000$ & Permissible for Drinking & 3 & $532.5-785.5$ & 33.33 \\
\hline & $1,000-3,000$ & Useful for Irrigation & 1 & 1061.67 & 11.11 \\
\hline & $>5,000$ & Unfit for Drinking and Irrigation & - & - & - \\
\hline \multirow[t]{5}{*}{$\% \mathrm{Na}$ based classification } & $<20$ & Excellent & - & - & - \\
\hline & $20-40$ & Good & - & - & - \\
\hline & $40-60$ & Permissible & 4 & $42.67-57.96$ & 44.44 \\
\hline & $60-80$ & Doubtful & 5 & $61.60-69.91$ & 55.56 \\
\hline & $>80$ & Unsuitable & - & - & - \\
\hline \multirow[t]{4}{*}{ SAR based classification } & $<10$ & Excellent ( S1) & 6 & 3.49- 9.35 & 66.67 \\
\hline & $10-18$ & Good $\quad($ S2 $)$ & 3 & $10.17-12.88$ & 33.33 \\
\hline & $19-26$ & Doubtful/ fair poor(S3) & - & - & - \\
\hline & $>26$ & Unsuitable (S4) & - & - & - \\
\hline \multirow{3}{*}{$\begin{array}{l}\text { RSC(Sodium } \\
\text { Carbonate) }\end{array}$} & $<1.25$ & Good & - & - & - \\
\hline & $1.25-2.5$ & Doubtful & - & - & - \\
\hline & $>2.5$ & Unsuitable & 9 & $4.04-33.93$ & 100 \\
\hline
\end{tabular}

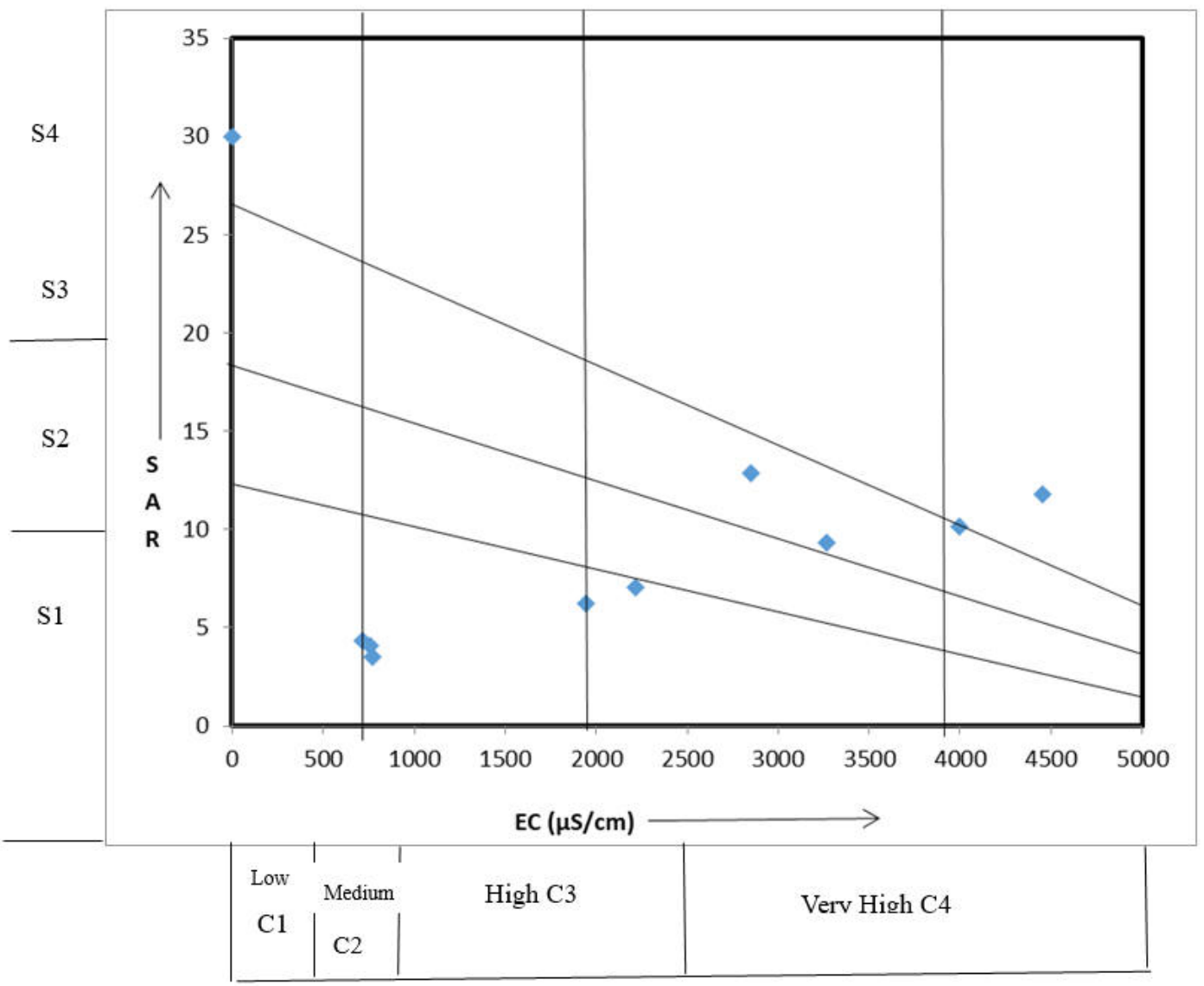

Figure 3: Salinity hazard diagram of groundwater samples of the study area

Figure 3 is a plot of Sodium hazard (SAR) values against the salinity hazard (conductivity) values obtained in the 
study area. This diagram shows that $67.65 \%$ (5) of groundwater samples belong to C3S1 water types, showing high and very high salinity and low sodium. Another group of $3(2.94 \%)$ water samples belong to C4S2 water classes having very high salinity and low sodium. One borehole plotted in the C3S1 division with very high salinity and low sodium. The sample belonging to $\mathrm{C} 2 \mathrm{~S} 1$ type revealing medium salinity and low sodium content accounted for $11.11 \%$.

\section{Conclusion}

The major water type identified in the study area is the $\mathrm{Na}^{+}-\mathrm{K}^{+}-\mathrm{HCO}_{3}{ }^{-}$water type and all the samples have the alkalis $\left(\mathrm{Na}^{+}+\mathrm{K}^{+}\right)$exceeding the alkaline earth $\left(\mathrm{Ca}^{2+}+\mathrm{Mg}^{2+}\right)$ cations. The weak acids $\left(\mathrm{CO}_{3}^{2-}+\mathrm{HCO}_{3}^{-}\right)$anions exceed the strong acid $\left(\mathrm{SO}_{4}{ }^{2-}+\mathrm{Cl}^{-}\right)$anions. Total hardness of the water samples under study showed high values and by classification all the water samples were very hard since they were all above $180 \mathrm{mg} / \mathrm{L} \mathrm{CaCO}_{3}$

Based on TDS classification, all the groundwater samples in the study area are suitable for drinking and irrigation. For the EC only $22.2 \%$ of the samples are good for drinking but with alkalinity classification all the water samples from Central Tongu are not suitable for drinking. The alkalinity hazard shows that $44.4 \%$ of the water samples are not suitable for irrigation. With regard to Sodium Absorption Ratio (SAR) all the groundwater samples are suitable for irrigation whilst on the other hand the Residual Sodium Carbonate values show that all the water samples are not suitable for irrigation.

\section{References}

Ackah, M., Agyemang, O., K Anim' K., Osei, J., Bentil, N. O., Kpattah, L, Gyamfi1, E. T. \& Hanson, J. E. K. (2011) Assessment of groundwater quality for drinking and irrigation: the case study of Teiman-Oyarifa Community, Ga East Municipality, Ghana:

Proceedings of the International Academy of Ecology and Environmental Sciences, 2011, 1(3-4):186-194

Al-Salim (2009) Ground water quality of areas selected near of Mosul city used for irrigation and drinking purposes, Al-Rafidain Eng, 17(3)

APHA, AWWA, WEF. (1998). Standard Methods for the Examination of water and wastewater, 20th ed., APHA. Washington, DC. pp 1-100.

DOE (Department Of Environment) (1997). Bangladesh Gazette, No. DA-1, Department of Environment, Ministry of Forest, pp 1324-1327

Durfor, C.N. and Becker, E., (1964) "Public water supplies of the 100 largest cities in the United States", In Geological Survey Water Supply, U.S. Government Printing Office, Washington, Paper No. 1812, pp. 364.

Ghana Statistical Service (2014). 2010 Population and Housing Census: District Analytical Report - Central Tongu District. pp.1-2.

Hem, J. D.(1985): Study and interpretation of the chemical characteristics of natural water. USGS Water Supply Paper, 2254, pp 117-120.

Jalali, M., (2005). Major ion chemistry of groundwater in the Bahar area, Hamadan, western Iran. Environ. Geol., 47: 763-772.

Kortatsi, B. K. (2007). Hydrochemical framework of groundwater in the Ankobra Basin, Ghana. Aquatic Geochemistry, 13, 41-74.

Kumar, A. (2004). Water Pollution. Nisha Enterprises New Delhi. pp. 33-35

Langmuir, D. (1997). Aqueous environmental geochemistry. Prentice Hall, Upper Saddle River, New Jersey 07458 .

Mahananda, H. B, Mahananda, M.R., and Mohanty, B. P.(2005). Studies on the Physco-chemical and Biological Parameters of a Fresh Water Pond Ecosystem as an Indicator of Water Pollution. Ecol. Env \& Cons.11 (34), 2005, pp 537-541.

Mirabbasi, R., Mazloumzadeh, S. M. and Rahnama, M. B., (2008). Evaluation of irrigation water quality using fuzzy logic. Research Journal of Environmental Sciences, 2(5): 340-352

Muhammad, S. S., Mumtaz, A., and Muhammad, A. K., (2002) Irrigational quality of underground water in Kasur district. Asian J Plant Sci 1:53-54

Oteze G. E., (1991). Potability of groundwater from the Rima Group aquifers in the Sokoto Basin. J. Min. Geol., 27(1): 17-23.

Piper, A. M., (1953): A graphic procedure in the geo-chemical interpretation of water analysis, USGS Groundwater Note no, 12.

Ravikumar, P., Somashekar, R. K. and Prakash K. L., (2015). Suitability Assessment of Deep Groundwater for Drinking and Irrigation Use in the Parts of Hoskote and Malur Taluks, Karnataka (India) Environmental Research, Engineering and Management, 71(1), 15-26

Schroeder. H. A., (1960): Relations between hardness of water and death rates from certain chronic and 
degenerative diseases in the United States, J. Chron disease, 12:586-591

Shaki, A. A., and Adeloye, A. J,. (2006). Evaluation of quantity and quality of irrigation water at Gadowa irrigation project in Murzuq basin, southwest Lybia. Agricultural Water Management, 84: 193-201

Siamak, G. and Srikantaswamy, S., (2009) Analysis of agricultural impact on the Cauvery river water around KRS dam. World Appl Sci J 6(8):1157-1169

Silva EIL, (2004). Quality of irrigation water in Sri Lanka status andtrends. Asian J WaterEnviron Pollut 1(1 \& 2):5-12

Sadashivaiah, C., Ramakrishnaiah, C. R. and Ranganna, G., (2008): Hydrochemical Analysis and Evaluation of Groundwater Quality in Tumkur Taluk, Karnataka State, India. Int. J. Environ. Res. Public Health 2008, 5(3) $158-164$.

USEPA. (2014). USEPA method 375: 4. Sulfate ${ }^{1}$ (SulfaVer 4 Method $\left.^{2}\right)$. ( $9^{\text {th }}$ Ed.). Hach Company/Hach Lange GmbH. pp. 3-5. DOC316.53.01135

WHO (2004). Guidelines for Drinking-Water Quality. 3rd ed., vol. 1 - Recommendations, Geneva. pp. 1-100.

Appendix 1.0: Ground water quality classification for agricultural planning in study area.

\begin{tabular}{ccccccc}
\hline Sampling sites & SAR & RSC & $\% \mathrm{Na}$ & $\begin{array}{c}\mathrm{EC} \\
(\mu \mathrm{S} / \mathrm{cm})\end{array}$ & $\begin{array}{c}\text { TDS } \\
(\mathrm{ppm})\end{array}$ & $\begin{array}{c}\text { Total Hardness } \\
\mathrm{mg} / \mathrm{L}_{\left(\mathrm{CaCO}_{3}\right)}\end{array}$ \\
\hline Agbadzikope 1 & 10.17 & 33.93 & 61.60 & 3997 & 311.5 & 1332.33 \\
Agbadzikope 2 & 12.88 & 23.85 & 69.91 & 2853 & 684.33 & 883.33 \\
Seva & 9.35 & 4.04 & 62.80 & 3270 & 785.5 & 846.0 \\
Asiekpe & 3.49 & 11.93 & 42.67 & 773 & 185.63 & 324.0 \\
Bakpa Dzave & 6.25 & 29.18 & 53.98 & 1947 & 467.67 & 876.67 \\
Kanikope & 11.80 & 29.42 & 63.83 & 4453 & 1061.67 & 1513.33 \\
Gbadagokope & 7.04 & 41.69 & 69.57 & 2217 & 532.5 & 455.0 \\
Amegakope & 4.33 & 15.5 & 57.96 & 720 & 172.45 & 220.0 \\
Avikope & 4.09 & 6.6 & 49.39 & 758 & 181.9 & 455.0 \\
\hline
\end{tabular}

Appendix 2.0 Physico- chemical parameters, major and minor constitents for groundwater sampled in nine communities in the Central Tongu District.

\begin{tabular}{|c|c|c|c|c|c|c|c|c|c|c|c|c|c|c|c|c|c|}
\hline $\mathrm{S} / \mathrm{N}$ & TOWN & $\mathrm{pH}$ & $\mathrm{T}(0 \mathrm{C})$ & $\mathrm{EC}(\mathrm{ms} / \mathrm{cm}$ & IDS (ppm & $\mathrm{HCO3}-$ & LLINITY & $\mathrm{Na}+(\mathrm{mg} /$ & $\mathrm{K}+(\mathrm{mg} / \mathrm{l})$ & Ca2t+ & Mg2+ & $\mathrm{Cl}$ & SO42- & N03- & P043- & F- & SIIICA \\
\hline 1 & AGBADZIKOPE 1 & 7.03 & 30.3 & 3996.67 & 311.5 & 1161.71 & 952.22 & 678.11 & 59.49 & 191.6 & 87.29 & 496.46 & 115.33 & 24.11 & 50.81 & 0.74 & 22.67 \\
\hline 2 & AGBADZIKOPE 2 & 6.97 & 29.1 & 2853.33 & 684.33 & 815.77 & 668.67 & 719.83 & 64.69 & 120.07 & 69.72 & 398.65 & 120 & 26.33 & 56.23 & 0.75 & 18.67 \\
\hline 3 & SEVA & 7.37 & 30.45 & 3270 & 785.5 & 385.3 & 315.83 & 543.88 & 52.48 & 129.86 & 75.89 & 305.48 & 107.5 & 25.18 & 43.99 & 0.91 & 26 \\
\hline 4 & ASIEKPE & 6.75 & 31.67 & 772.67 & 185.63 & 419.68 & 344 & 134.64 & 56.19 & 50.23 & 46.9 & 112.45 & 42.33 & 27.94 & 44.39 & 0.32 & 18.33 \\
\hline 5 & BAKPA DZAVE & 7.32 & 28.9 & 1947 & 467.67 & 1372.6 & 393.11 & 346.21 & 48.84 & 72.3 & 95.47 & 309.48 & 34 & 24.99 & 74.03 & 0.5 & 19.33 \\
\hline 6 & KANIKOPE & 7.09 & 30.2 & 4453.33 & 1061.67 & 1250.96 & 864.78 & 856.4 & 45.94 & 147.23 & 150.67 & 610.14 & 92 & 27.48 & 43.88 & 32 & 18.33 \\
\hline 7 & GBADAGOKOPE & 7.34 & 29 & 2217.5 & 532.5 & 1135.62 & 930.83 & 444.92 & 42.75 & 99.87 & 30.59 & 251.31 & 94 & 24.31 & 76.06 & 0.22 & 16 \\
\hline 8 & AMEGAKOPE & 7.35 & 30.4 & 720 & 172.45 & 527.04 & 432 & 140.69 & 17.41 & 36.79 & 25.8 & 85.06 & 7 & 27.92 & 136.3 & 0.58 & 16 \\
\hline 9 & AVIKOPE & 7.4 & 29.4 & 758 & 181.9 & 331.03 & 271.33 & 186.52 & 17.34 & 44.55 & 67.65 & 120.08 & 49.5 & 52.77 & 32.27 & 1.2 & 7.5 \\
\hline
\end{tabular}

